\title{
PERAN GURU DALAM PROSES KREATIF BATIK TULIS PESERTA DIDIK DI SEKOLAH DASAR
}

\author{
Probosiwi* \\ Nurul Aulia Dewi \\ Pendidikan Guru Sekolah Dasar, Fakultas Keguruan dan Ilmu Pendidikan, Universitas Ahmad Dahlan \\ Jl. Ki Ageng Pemanahan 19 Sorosutan, Umbulharjo, Yogyakarta, Indonesia \\ *E-mail: probosiwi@pgsd.uad.ac.id
}

Artikel diterima: 30 Juli 2020; disetujui: 30 November 2020

\begin{abstract}
This article aims to describe the process of student creativity, explain the role of teachers in developing student creativity, and explain the supporting and inhibiting factors in developing students' creativity in the local subject "batik tulis" at SD Muhammadiyah Bantul City. The method used is a qualitative type with a descriptive approach. Data collection techniques are carried out through observation, interviews, and document review. The results showed that the creative process of students in making written batik works well, namely from the aspect of the individual (person), encouragement (press), critical thinking skills (process), and tangible creativity (product). The teachers perform their roles as well as demonstrator, class manager, mediator, facilitator, and evaluator.
\end{abstract}

Keywords: the role of the teacher; creativity process; local subject "batik tulis"

\begin{abstract}
Abstrak: Tujuan artikel ini untuk mendeskripsikan proses kreativitas peserta didik, peran guru dalam mengembangkan kreativitas peserta didik, serta menjelaskan faktor pendukung dan penghambat dalam mengembangkan kreativitas peserta didik pada mata pelajaran muatan lokal batik tulis di SD Muhammadiyah Bantul Kota. Metode kualitatif digunakan dengan pendekatan deskriptif. Teknik pengumpulan data dilakukan dengan metode observasi, wawancara, dan telaah dokumen. Hasil penelitian menunjukkan bahwa proses kreativitas peserta didik dalam membuat karya batik tulis berlangsung dengan baik, yakni dari aspek individu, dorongan, keahlian berpikir kritis, dan kreativitas berwujud. Guru menjalankan perannya dengan baik, yakni sebagai demonstrator, pengelola kelas, mediator, fasilitator, dan evaluator.
\end{abstract}

Kata kunci: peran guru; kreativitas; muatan lokal batik tulis

\section{PENDAHULUAN}

Indonesia merupakan negara multikultur yang memiliki suku, ras, bahasa, agama, dan budaya dengan keanekaragaman kearifan lokalnya. Setiap daerah memiliki suatu kearifan lokal masingmasing yang wajib untuk dilestarikan oleh rakyatnya. Hal tersebut sesuai dengan pendapat (Basari, 2014) yang menyatakan bahwa Indonesia memiliki berbagai macam adat istiadat, tata cara, kesenian, kerajinan, dan keterampilan daerah yang masing-masing memiliki suatu ciri khas yang harus dilestarikan keberadaannya karena mampu untuk memperkaya nilai-nilai luhur kehidupan 
bangsa Indonesia. Pemerintah Indonesia telah menetapkan kurikulum muatan lokal sebagai salah satu mata pelajaran yang wajib ada di pendidikan dasar dan menengah.

Kurikulum muatan lokal yang memanfaatkan kearifan lokal dan potensi daerah memiliki banyak manfaat bagi daerah maupun peserta didik. Untuk daerah sendiri dapat mengangkat khas potensi daerahnya sehingga lebih dikenal oleh masyarakat luar. Selain itu, bisa mendatangkan manfaat ekonomi bagi masyarakat. Beberapa manfaat untuk peserta didik juga dapat sebagai sarana untuk meningkatkan kreativitas serta dapat menjadi bekal bagi peserta didik untuk berkarya setelah menyelesaikan studinya (Ma'unah dkk., 2020). Pembelajaran muatan lokal dilaksanakan untuk mengembangkan berbagai keterampilan yang dimiliki peserta didik melalui potensi daerah seperti budaya, bahasa, dan adat istiadat (Latifah dkk., 2019).

Penentuan isi muatan lokal yang terdapat di pembelajaran sekolah harus disesuaikan dengan keadaan daerah. Salah satu kabupaten yang mewajibkan adanya pembelajaran muatan lokal ialah kabupaten Bantul. Pemerintah Kabupaten Bantul mewajibkan seluruh sekolah terdapat mata pelajaran muatan lokal membatik (Samawi, 2010). Salah satu sekolah dasar di Kabupaten Bantul, yaitu SD Muhammadiyah Bantul Kota menerapkan pembelajaran batik sebagai salah satu dari muatan local yang diajarkan kepada peserta didiknya. Jenis batik yang diajarkan adalah batik tulis yang digambar pada kain dan peewarnaannya menggunakan pewarna dari malam (lilin) yang dipanaskan dalam wajan dan alat canthing sebagai media melukisnya.

Batik tulis adalah salah satu materi di dalam mata pelajaran seni rupa, di mana batik tulis menurut teknik pembuatannya dapat diklasifikasikan menjadi 2, yaitu batik tradisional dan batik dengan gaya modern atau bebas. Batik juga masuk dalam seni batik yang merupakan jenis dari seni kriya tekstil (Qur'ani dkk., 2019). Batik telah dikenal secara luas sebagai salah satu warisan budaya Indonesia (Rante \& Safrodin, 2019). Berdasarkan informasi tersebut, para peserta didik diarahkan oleh guru untuk bisa membuat batik dengan teknik canthing. Pembelajaran muatan lokal batik tulis dilaksanakan secara teoretis dan praktik langsung.

Dalam pembelajaran, guru harus mampu memaksimalkan perannya sebagai pendidik karena akan menentukan masa depan peserta didik. Hal ini senada dengan pernyataan Usman, bahwa guru merupakan seorang pendidik yang bertugas menjalankan perannya sebagai demonstrator, pengelola kelas, mediator, fasilitator, dan evaluator (Usman, 2013). Pada pembelajaran muatan lokal batik tulis, maka dibutuhkan suatu kreativitas pada diri peserta didik untuk menghasilkan produk batik tulis yang maksimal. Untuk mengembangkan kreativitas yang dimiliki oleh masingmasing peserta didik, maka guru diharapkan mampu untuk menjalankan perannya dengan baik.

Kreativitas peserta didik sebagai suatu kemampuan peserta didik untuk menghasilkan macammacam ide melalui proses berfikir yang luas dan beragam. Guru sebagai seorang yang memegang peran dalam proses pembelajaran dan berinteraksi langsung dengan peserta didik sudah seharusnya 
dapat menanamkan kebiasaan berpikir kreatif pada peserta didik (Ardianti dkk., 2017). Kreativitas merupakan kemampuan yang dimiliki seseorang untuk menemukan dan menciptakan suatu hal baru, atau juga menemukan kombinasi baru yang memiliki kualitas yang berbeda sebelumnya (Astuti \& Aziz, 2019). Lebih lanjut, Martin menuliskan bahwa kreativitas merupakan kumpulan kriteria yang cenderung terdiri dari: menghasilkan sesuatu yang baru, memiliki nilai, adaptif, relevan dengan masalah dan diakui (Martin \& Wilson, 2017). Kreativitas mengacu pada penciptaan kebaruan dan respon yang sesuai, produk, atau solusi untuk tugas terbuka (Hanif dkk., 2019). Kreativitas adalah kemampuan seseorang untuk melahirkan sesuatu yang baru baik berupa gagasan maupun karya nyata, yang relatif berbeda dengan apa yang ada sebelumnya (Permatasari, 2018). Kreativitas sebagai konstruksi yang terdiri dari kesulitan untuk mendefinisikan dan mengukur (Thuneberg dkk., 2018).

Untuk memberikan ruang kreativitas bagi anak-anak, diperlukan konsep sekolah terbuka dan mencoba menerapkan pembelajaran yang membutuhkan perkembangan psikologis siswa mereka (Lian dkk., 2018). Upaya yang dilakukan dapat dari segi materi; proses pembelajaran, perbaikan dan dukungan sarana prasarana; peningkatan kemampuan guru dalam mengajar melalui penataran atau pelatihan, pengurangan; pembagian materi menjadi bagian-bagian yang lebih sederhana (penyederhanaan muatan materi dalam kurikulum) atau peningkatan mutu input (peserta didik) di sekolah. Aktivitas mental untuk mengembangkan atau menemukan ide-ide asli (orisinil), estetis, konstruktif yang berhubungan dengan pandangan konsep, dan menekankan pada aspek berpikir intuitif dan rasional (Ishak dkk., 2017). Untuk dapat menciptakan situasi pembelajaran yang kreatif, maka dibutuhkan langkah-langkah pembelajaran kreatif.

Langkah-langkah pembelajaran kreatif termaktub ke dalam "Four P" (4P) yaitu person (individual), press (lingkungan sekitar), process (keahlian berpikir kreatif), dan product (hasil akhir kreativitas). Intervensi kreativitas yang sukses harus menyentuh pada 4Ps, serta memberikan pilihan kepada peserta didik, menciptakan lingkungan yang mendukung, memungkinkan anakanak untuk menunjukkan inisiatif, dan melibatkan mereka dalam proses pengambilan keputusan (Falconer dkk., 2018). Aspek person merupakan sebuah upaya meningkatkan kreativitas di dalam individu. Aspek press (meningkatkan kreativitas melalui lingkungan) merupakan faktor intrinsik dari orang yang mempengaruhi kreativitas seseorang dan faktor lingkungan eksternal juga memiliki efek tidak langsung pada potensi kreatif. Aspek process yang dimaksud adalah unsur proses kreativitas terdiri dari motivasi, persepsi, pembelajaran, berpikir, dan berkomunikasi yang dapat diajarkan dan digunakan untuk menumbuhkan kreativitas di lingkungan yang sesuai dan diberi pengalaman yang tepat. Aspek product (kreativitas berwujud), merupakan bagian dari proses pemikiran kreatif biasanya menghasilkan produk kreatif, yang merupakan perwujudan ide, atau pemikiran orisinal seseorang ke dalam bentuk nyata. 
Dalam pembelajaran tentunya akan terdapat siswa yang kreatif dalam membuat suatu karya secara kreatif dalam bidang seni ataupun bidang lainnya. Hal tersebut sesuai dengan pendapat Chaplin menyatakan bahwa kreativitas adalah suatu kemampuan peserta didik dalam menghasilkan suatu hasil karya, salah satunya ialah karya dalam bentuk seni (Euis, 2010). Guru juga memiliki peranan penting dalam meningkatkan prestasi belajar siswa. Dalam hal ini, terjadinya komunikasi yang intensif antara siswa dengan guru akan meningkatkan kualitas proses pembelajaran (Maryen dkk., 2018). Peran guru dibagi sebagai demonstrator, pengelola kelas, motivator, mediator dan fasilitator, serta evaluator (Mardiah, 2020). Untuk mengembangkan kreativitas yang dimiliki oleh setiap peserta didik maka diperlukan seorang guru yang mampu untuk menjalankan perannya secara optimal. Dengan membuat suatu hasil karya kerajinan batik tulis maka akan melatih kreativitas peserta didik untuk mengembangkan ide yang dimilikinya serta mampu melestarikan hasil karya kerajinan batik tulis yang menjadi kerajinan lokal daerah tempat tinggalnya. Salah satu sekolah yang berada di Kabupaten Bantul yang menerapkan kurikulum muatan lokal membatik ialah SD Muhammadiyah Bantul Kota.

Berdasarkan hasil observasi di kelas IV A SD Muhammadiyah Bantul Kota pada tanggal 16 Oktober 2019, terdapat mata pelajaran muatan lokal membatik di sekolah tersebut. Salah satu jenis batik yang terdapat di sekolah tersebut ialah batik tulis. Batik tulis merupakan batik yang dihiasi dengan berbagai macam motif batik dengan menggunakan suatu alat yang disebut canting. Alat canting ini terbuat dari tembaga yang berbentuk menyerupai pipa kecil untuk tempat keluarnya malam pada saat membentuk motif batik di permukaan kain (Arini, 2011). Pada pembelajaran muatan lokal batik tulis, guru melaksanakan perannya sebagai demonstrator, pengelola kelas, fasilitator, mediator, dan evaluator. Akan tetapi, belum diketahuinya secara detil mengenai peran guru dalam menjalankan perannya guna untuk mengembangkan kreativitas peserta didik kelas IV A SD Muhammadiyah Bantul Kota. Berdasarkan wawancara dengan guru muatan lokal batik tulis pada tanggal 16 Oktober 2019, pembelajaran muatan lokal batik tulis di SD Muhammadiyah Bantul Kota yakni berupa pembelajaran teori dan praktik. Guru terlebih dahulu menjelaskan teori mengenai konsep dasar batik agar peserta didik mampu mengetahui konsep dasar batik dengan baik. Setelah itu, guru memperkenalkan macam-macam motif batik kemudian memberi kesempatan kepada peserta didik untuk membuat motif batik di atas kertas, di atas kain, hingga tahap mencanting dengan menggunakan alat canting dan lilin malam.

Terdapat faktor pendukung dan penghambat yang dihadapi guru dalam mengembangkan kreativitas peserta didik. Faktor pendukung menurut ialah rangsangan mental dan kondisi lingkungan. Guru muatan lokal batik tulis kelas IVA mampu menghargai dan menerima potensi kreatif yang dimiliki oleh setiap peserta didik dan guru mampu menciptakan kondisi lingkungan yang menyenangkan sehingga peserta didik mampu merasa nyaman dalam mengembangkan ide 
kreatif yang dimilikinya dengan membuat kerajinan batik tulis (Euis, 2010). Adapun faktor penghambat yang dihadapi oleh guru dalam pelaksanaan pembelajaran muatan lokal batik tulis ialah penundaan evaluasi, pemberian hadiah, persaingan, dan lingkungan yang membatasi (Usman, 2013). Berdasarkan latar belakang yang telah diuraikan tersebut, penulis (1) menggali informasi dan mendeskripsikan mengenai proses kreativitas peserta didik dalam mengikuti kegiatan pembelajaran muatan lokal batik tulis; (2) mendeskripsikan mengenai peran guru dalam mengembangkan kreativitas peserta didik dari sisi demonstrator, pengelola kelas, mediator, fasilitator, dan evaluator; (3) mendeskripsikan mengenai faktor pendukung dan faktor penghambat guru dalam mengembangkan kreativitas peserta didik dalam pembelajaran muatan lokal batik tulis..

\section{METODE}

Metode yang digunakan adalah jenis kualitatif dengan pendekatan deskriptif. Teknik pengumpulan data dilakukan dengan wawancara, observasi, dan telaah dokumen. Pada penelitian ini, penulis memilih tipe wawancara tidak terstruktur yaitu kebalikan dari wawancara terstruktur, tidak ada pedoman khusus, dimulai dengan mengeksplorasi suatu topik umum bersama-sama dengan partisipan.

Teknik analisis data dalam penelitian ini menggunakan tipe naratif. Penulis memilih pendekatan dalam analisis naratif yaitu menulis dengan mengorganisir dan menyajikan data penelitian, menggunakan struktur narasi untuk bercerita.

Subjek dalam penelitian ini ialah peserta didik kelas IVA dan guru muatan lokal batik tulis kelas IVA SD Muhammadiyah Bantul Kota. Objek dalam penelitian ini adalah peran guru dalam mengembangkan kreativitas peserta didik pada mata pelajaran muatan lokal batik tulis di SD Muhammadiyah Bantul Kota. Penelitian dilaksanakan di SD Muhammadiyah Bantul Kota yang beralamat di Jl. KH Hasyim Asyari, Kurahan, Bantul, Kec. Bantul, Kabupaten Bantul, Provinsi Daerah Istimewa Yogyakarta Kode Pos 55711.

\section{HASIL DAN PEMBAHASAN}

Berdasarkan hasil penelitian yang telah didapatkan tentang peran guru dalam mengembangkan kreativitas peserta didik pada mata pelajaran muatan lokal batik tulis di SD Muhammadiyah Bantul Kota, maka dilakukan pembahasan lebih lanjut yakni sebagai berikut.

\section{Proses Kreativitas Peserta Didik Pada Saat Pembelajaran Praktik Membuat Batik Tulis}

\section{Individu (Person)}

Peserta didik kelas IVA masing-masing memiliki kreativitas yang berbeda-beda. Mereka cenderung untuk berusaha membuat batik tulis sesuai dengan keinginan dan imajinasi yang mereka miliki. Peserta didik selalu ingin berusaha untuk melakukan latihan untuk menghasilkan 
produk yang maksimal, yakni dengan cara mencari motif batik tulis dari buku paket, internet, menggambar dengan menggabungkan motif yang telah didapatkannya, hingga menggambar sesuai keinginan dan imajinasi mereka. Peserta didik kelas IVA selalu bersemangat untuk melakukan suatu hal yang baru dan selalu mengajukan pertanyaan bagaimana cara mencanting yang benar kepada guru. Hal tersebut dilakukan peserta didik dikarenakan mereka baru pertama kali mengikuti pembelajaran praktik membatik hingga tahap mencanting. Akan tetapi, walaupun mereka baru mencoba membuat batik tulis hingga tahap mencanting, mereka tetap bersemangat untuk mengeksplorasi pengetahuan serta melakukan kegiatan yang unik. Hal ini sejalan dengan pengertian kreativitas dimana terkait dengan kemampuan seseorang melahirkan karya nyata berbeda dari sebelumnya (Permatasari, 2018). Dalam hal ini pula peserta didik dituntut untuk dapat menerjemahkan materi serta mempraktikan teknik dengan mendorong dirinya berpikir kreatif dalam menciptakan motif batik.

\section{Belajar dari Lingkungan (Press)}

Pada pembelajaran praktik membatik, peserta didik mendapatkan dorongan kuat dari dalam dirinya dan juga lingkungan sekitarnya. Peserta didik kelas IVA memiliki semangat yang tinggi dalam membuat motif batik tulis di atas kertas, di atas kain, ataupun hingga proses mencanting, yakni dapat diketahui peserta didik bersemangat untuk mencari motif batik yang akan di gambar sesuai dengan ide dan imajinasi yang mereka miliki kemudian mencurahkan ide yang dimiliki ke atas kertas ataupun kain mereka masing-masing. Akan tetapi, terdapat juga beberapa peserta didik yang kurang bersemangat untuk menggambar motif batik tulis, tetapi mereka mendapatkan support dari orangtua, guru, dan teman-temannya yang telah selesai menggambar sehingga merekapun menyelesaikan karyanya dengan baik. Berdasarkan hasil wawancara kepada guru, bentuk dorongan dari orangtuanya ialah berupa membantu mencarikan motif batik yang akan dibuat oleh anaknya apabila anak tersebut merasa kesulitan dan juga berupa semangat agar motif batik tulis yang digambarnya mampu selesai dengan baik. Hal ini sesuai dengan pentingnya proses komunikasi. Terjadinya komunikasi yang intensif antara siswa dengan guru akan meningkatkan kualitas proses pembelajaran (Maryen dkk., 2018).

Bentuk dorongan dari guru ialah mendampingi peserta didik yang merasa kesulitan ketika menggambar motif batik tulis ataupun ketika mencanting dan juga memberikan dorongan semangat kepada peserta didik berupa memberikan semangat bahwa semua orang memiliki kemampuan masing-masing dan pasti ketika mau berusaha semua akan selesai dengan baik. Sedangkan bentuk dorongan dari teman sekelasnya ialah mereka mendampingi temannya yang belum selesai menggambar ataupun mencanting, mereka memberikan semangat dan motivasi ke temannya agar mampu selesai juga. Dengan adanya dorongan kuat dari dalam diri peserta didik 
dan lingkungan sekitarnya maka peserta didik mampu mengikuti kegiatan pembelajaran dengan semangat dan mampu menghasilkan hasil secara maksimal.

\section{Keahlian Berpikir Kreatif (Process)}

Peserta didik diberikan kesempatan kepada oleh guru untuk membuat batik tulis sesuai dengan keinginannya dan mempersilahkan motif apa yang akan di buat. Peserta didik juga mampu memanfaatkan sarana dan prasarana yang ada di kelas untuk berlangsungnya pembelajaran membatik. Sebuah kreativitas akan berkembang dengan baik apabila adanya kerjasama yang maksimal antara aspek pribadi dan pendorong pada diri peserta didik (Khanafiyah \& Rusilowati, 2010).

Dengan adanya semangat dari dalam diri peserta didik dan adanya dorongan dari lingkungannya maka peserta didik mampu menjalankan proses membuat batik tulis secara maksimal yakni dapat diketahui bahwa peserta didik kelas IVA memiliki suatu pribadi yang cenderung ingin tahu dan gemar untuk mencoba suatu yang baru dan menemukan inspirasi mengenai motif batik apa yang akan digunakannya. Proses peserta didik berkegiatan membatik tulis disajikan pada Gambar 1. Hal ini sejalan pula dengan pendapat yang menyatakan bahwa untuk memberikan ruang kreativitas bagi anak-anak, diperlukan konsep sekolah terbuka dan mencoba menerapkan pembelajaran yang membutuhkan perkembangan psikologis siswa mereka (Lian dkk., 2018).

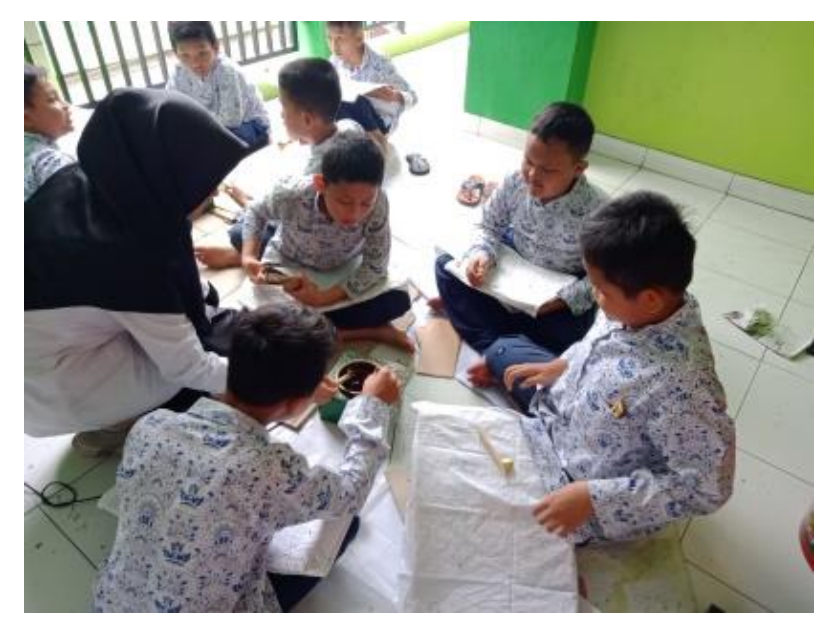

Gambar 1. Peserta didik pada Aspek Proses dalam Kegiatan Praktik Batik Tulis

\section{Kreativitas Berwujud (Product)}

Peserta didik kelas IVA mampu menghasilkan produk batik tulis dengan maksimal karena mereka mampu membuat batik tulis dengan komponen titik, garis, serta warna yang indah sesuai dengan keinginan dan imajinasi mereka masing-masing. Produk akhir dalam kegiatan praktik membatik tulis disajikan pada Gambar 2. Komponen garis dan titik yang dibuat oleh peserta didik dapat ditemukan pada proses akhir pada kegiatan mencanting dengan menggunakan lilin malam 
dan alat canting. Peserta didik memberikan komponen titik dan garis. Komponen garis yang digunakan oleh peserta didik dalam membuat produk tulis berupa garis tegak lurus, garis lengkung, garis miring, garis sejajar, garis gelombang, garis zig-zag, dan garis spiral. Sedangkan komponen titik digunakan untuk memberikan isen-isen pada ruang yang masih kosong di kain untuk memperindah batik tulis yang telah mereka buat. Akan tetapi, kegiatan praktik membuat produk batik tulis tidak sampai tahap akhir yakni mewarnai kain dikarenakan sekolah lockdown dan libur.

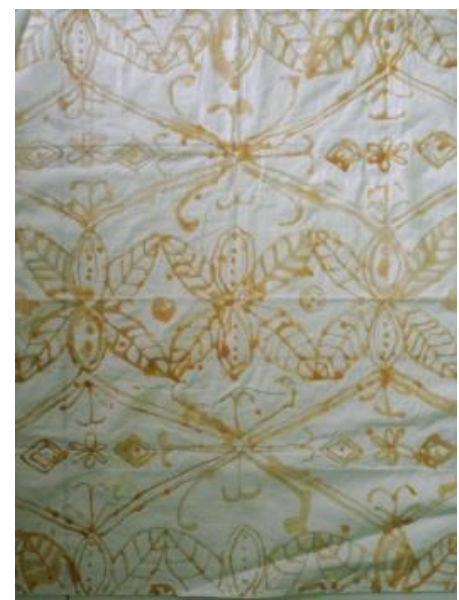

Gambar 2. Contoh Produk Kegiatan Praktik Batik Tulis

\section{Peran Guru dalam Mengembangkan Kreativitas Peserta Didik pada Pembelajaran Muatan}

\section{Lokal Batik Tulis}

\section{Peran Guru Sebagai Demonstrator}

Guru muatan lokal batik tulis kelas IVA SD Muhammadiyah Bantul Kota sebelum pembelajaran dimulai, guru sudah menyiapkan materi yang akan disampaikan kepada peserta didik dalam bentuk Powerpoint ataupun video pembelajaran mengenai batik tulis. Hal tersebut dipersiapkan oleh guru secara matang dikarenakan guru tersebut bukan berasal dari jurusan seni, melainkan jurusan Pendidikan Guru Sekolah Dasar (PGSD). Akan tetapi, guru tersebut selalu berusaha semaksimal mungkin dalam mempersiapkan materi ajar yang akan disampaikan agar peserta didik mampu memahaminya dengan mudah.

Guru muatan lokal batik tulis kelas IVA SD Muhammadiyah Bantul Kota selalu berusaha mempelajari materi pelajaran yang ada di buku cetak, kemudian mencari materi ajar dari internet dikarenakan materi pelajaran yang ada di buku paket kurang lengkap. Guru selalu kreatif dalam menjelaskan materi pelajaran, seperti menyediakan berbagai sumber dan media pelajaran yang beranekaragam, agar peserta didik mampu memiliki wawasan yang luas dalam memahami materi pelajaran batik tulis. Guru muatan lokal batik tulis SD Muhammadiyah Bantul Kota telah menyusun rencana pelaksanaan pembelajaran (RPP) yang dibuat bersama guru kelas 4 lainnya. Jadi, guru-guru tersebut dalam meyusun rencana pelaksanaan pembelajaran dilakukan secara bersama-sama. Selain itu, guru menentukan tujuan pembelajaran khusus dalam setiap pertemuan 
yakni agar materi ajar mampu tersampaikan dengan baik kepada peserta didik dan mampu mencapi hasil belajar yang maksimal.

Guru muatan lokal batik tulis kelas IVA SD Muhammadiyah Bantul Kota mampu mempelajari dan menguasai materi ajar yang akan disampaikan kepada peserta didik dan juga mampu mengembangkan materi ajar dengan mencari sumber dari internet. Materi ajar agar mampu tersampaikan dengan baik, guru berusaha menyiapkan berbagai metode pelajaran yang sesuai agar peserta didik tidak merasa jenuh dalam mengikuti kegiatan pembelajaran yang berlangsung. Upaya mempersiapkan metode pelajaran tersebut dilakukan agar penyampaian materi tidak hanya berupa penyampaian materi secara garis besar saja, melainkan menyampaikan materi menurut kehidupan sehari-hari agar peserta didik mampu memahaminya dengan mudah dan mampu mengambil suatu nilai yang mampu bermanfaat bagi kehidupan peserta didik. Hal ini senada dengan pendapat yang menyatakan bahwa guru tidak hanya berperan untuk menyampaikan materi tapi dapat kepada komunikasi mendiskusikan materi antara guru dan siswa (Inah, 2015).

Guru muatan lokal batik tulis kelas IVA SD Muhammadiyah Bantul Kota selalu berusaha menunjukkan sikap-sikap terpuji yang di contoh oleh peserta didik. Sikap terpuji tersebut antara lain: dalam berpakaian, menggunakan bahasa yang sopan dan santun, disiplin waktu, disiplin dalam hal mengumpulkan tugas, jujur terhadap perbuatan yang telah diperbuat, dan sebagainya.

\section{Peran Guru Sebagai Pengelola Kelas}

Dalam pembelajaran teori muatan lokal batik tulis guru menyusun tempat duduk peserta didik, yakni setiap minggunya peserta didik duduk di tempat secara bergantian misalnya minggu ini peserta didik tersebut duduk paling depan maka minggu selanjutnya duduk di bangku nomor dua, dan seterusnya. Terkadang tempat duduk di setting menjadi melingkar juga. Hal tersebut dilakukan agar peserta didik tidak jenuh dengan tempat belajar yang itu-itu saja. Guru muatan lokal batik tulis selalu berusaha menjaga kebersihan kelas dengan cara mendisiplikan peserta didik untuk melaksanakan piket kelas setiap harinya. Ketika pembelajaran praktik berlangsung, guru mengajarkan kepada peserta didiknya untuk menjaga kebersihan halaman depan kelas agar proses belajar praktik yang berlangsung mampu menimbulkan rasa aman dan menyenangkan bagi peserta didik. Dengan melaksanakan pembelajaran praktik di luar kelas maka akan merangsang peserta didik untuk belajar dan mengembangkan kreativitasnya dalam menghasilkan produk batik tulis.

Guru muatan lokal batik tulis mampu menyediakan dan menggunakan fasilitas kelas sekolah untuk kegiatan pembelajaran, yakni dalam pembelajaran teori guru menggunakan fasilitas wifi agat terhubung ke internet untuk mencari materi ajar dan juga proyektor LCD untuk menampilkan Powerpoint berupa materi ajar yang disampaikan kepada pesera didik. Pada kegiatan praktik guru mampu menggunakan fasilitas halaman depan kelas sebagai sarana untuk pelaksanaan praktik membatik sebagaimana disajikan pada Gambar 3. Guru berperan sebagai pengelola kelas dapat 
diketahui bahwa guru muatan lokal batik tulis mampu membuat peserta didik tertarik untuk mengikuti pembelajaran yang berlangsung dengan cara menggunakan metode pelajaran yang beranekaragam seperti ceramah dan diskusi, serta membantu peserta didik untuk memperoleh suatu hasil belajar yang diharapkan yakni guru mampu membimbing peserta didiknya agar mudah memahami materi pelajaran yang disampaikan serta berusaha mengadakan evaluasi ketika akhir pembelajaran. Guru harus selalu berusaha menyampaikan materi ajar menggunakan bahasa yang mudah dipahami oleh peserta didik (Pontoh, 2013; Sani, 2013). Guru mampu menciptakan proses sosial yang akrab kepada seluruh peserta didik dengan cara mengadakan diskusi pada saat pembelajaran praktik dan berkelompok dalam kegiatan mencanting.

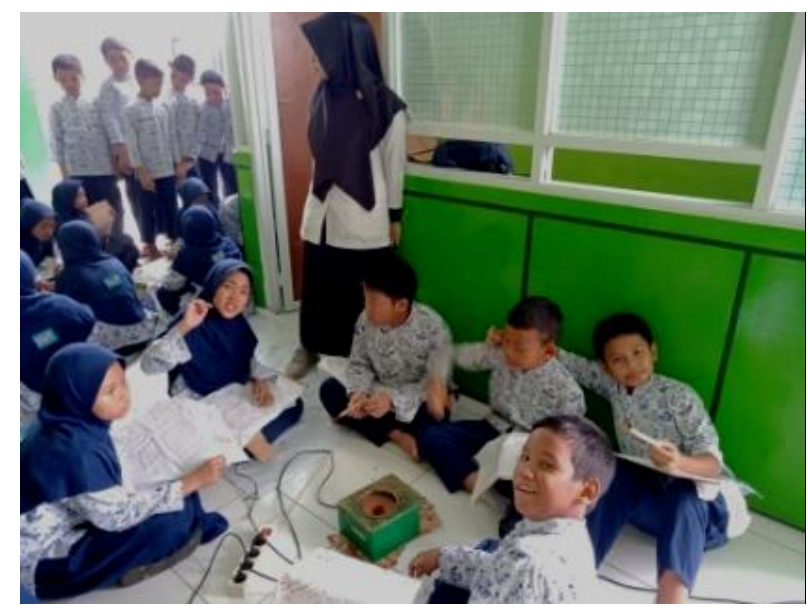

Gambar 3. Peran Guru sebagai Pengelola Kelas pada Kegiatan di Halaman Kelas

\section{Peran Guru Sebagai Mediator}

Guru muatan lokal batik tulis kelas IVA SD Muhammadiyah Bantul Kota memiliki suatu keterampilan untuk memilih dan menggunakan media pembelajaran yangs sesuai dengan materi pelajaran yang disampaikan yakni pada pembelajaran teori ataupun praktik. Dalam kegiatan pembelajaran teori guru menggunakan Powerpoint untuk menjelaskan konsep dasar batik tulis yaitu seperti pengertian batik tulis dan macam-macam motif batik tulis. Terkadang guru menggunakan media pembelajaran berupa print an kertas macam-macam motif batik tulis yang akan dibagikan ke peserta didik serta menggunakan media pembelajaran contoh motif batik tulis karya kakak kelas peserta didik. Sedangkan pada pembelajaran praktik membatik, guru menggunakan media pembelajaran berupa video pembelajaran tentang proses pembuatan produk batik tulis. Dengan adanya media pembelajaran maka akan lebih membantu mengefektifkan proses pembelajaran yang berlangsung, yakni peserta didik mampu melihat secara nyata dan langsung mengenai produk batik tulis yang sedang dijelaskan.

Guru muatan lokal batik tulis kelas IVA selalu berusaha berinteraksi dengan baik kepada seluruh peserta didik dengan cara mengajukan berbagai pertanyaan kepada masing-masing peserta didik apabila terdapat peserta didik yang belum memahami materi yang sedang disampaikan. Guru 
juga terkadang berkomunikasi kepada peserta didik dengan menggunakan bahasa campuran yaitu bahasa Indonesia dan bahasa Jawa dikarenakan terdapat beberapa peserta didik yang sulit berinteraksi menggunakan bahasa Indonesia. Guru mampu mendorong berlangsungnya tingkah laku sosial pada diri peserta didik dengan menggunakan metode pembelajaran seperti diskusi untuk meningkatkan interaksi antar peserta didik. Dengan adanya media pembelajaran, maka akan mempermudah guru dalam berkomunikasi dan berinteraksi kepada peserta didik. Sebelum kegiatan pembelajaran dimulai, guru terlebih dahulu mempelajari materi ajar yang akan disampaikan kemudian memikirkan media pembelajaran apa yang cocok digunakan untuk materi ajar tersebut. Seperti misalnya macam-macam motif batik tulis, guru menggunakan media pembelajaran berupa gambar print an motif batik tulis dan contoh karya kakak kelas peserta didik.

\section{Peran Guru Sebagai Fasilitator}

Dalam kegiatan pembelajaran yang berlangsung guru menyediakan sumber belajar berupa buku paket yang telah disediakan oleh sekolah dan internet guna untuk melengkapi materi ajar yang berada di buku paket dikarenakan materi yang ada di buku paket kurang lengkap. Dalam kegiatan teori ataupun praktik, guru selalu berusaha untuk memanfatakan fasilitas yang disediakan oleh sekolah seperti LCD proyektor guna untuk menampilkan materi pelajaran dan video pembelajaran. Hal tersebut dilakukan agar memudahkan penyampaian materi ajar kepada peserta didik.

Pada kegiatan pembelajaran teori, guru mampu menyediakan sarana dan prasarana yang ada di sekolah yakni memanfaatkan ruang kelas dengan baik dengan cara menjelaskan materi pelajaran dengan menggunakan LCD proyektor melalui Powerpoint. Sedangkan pada kegiatan pembelajaran praktik, guru memberikan kesempatan kepada peserta didik untuk menggambar di posisi yang nyaman menurut mereka, serta pada kegiatan praktik mencanting guru memanfaatkan halaman depan ruang kelas sebagai tempat dilaksanannya praktik membuat produk batik tulis. Guru juga menyiapkan alat dan bahan yang digunakan untuk kegiatan mencanting batik tulis yakni menyiapkan banner sebagai alas tempat duduk peserta didik agar tidak kotor dan lantai tidak terkena lilin panas, menyiapkan kompor, kardus, kain, dan lilin malam. Dengan guru berusaha menyediakan sumber belajar yang maksimal dan sesuai dengan materi ajar yang akan disampaikan maka tujuan pembelajaran akan tercapai dengan maksimal (Hendarwati, 2013).

\section{Peran Guru Sebagai Evaluator}

Guru muatan lokal batik tulis kelas IVA SD Muhammadiyah Bantul Kota berusaha melakukan evaluasi di setiap akhir pembelajaran teori ataupun praktik. Guru berusaha melakukan penilaian baik dari segi kognitif, afektif, dan psikomotor. Pada pembelajaran teori biasanya guru melakukan Tanya jawab kepada peserta didik mengenai materi pelajaran yang telah dipelajari guna mengetahui apakah materi pelajaran yang telah dijelaskan sudah dipahami oleh peserta didik 
atau belum. Dan juga guru melaksakan kuis dan mengerjakan buku cetak di setiap bab pembahasan muatan lokal batik tulis hal tersebut dilakukan guna mengukur kemampuan kognitif peserta didik mengenai batik tulis yang telah dipelajari. Pada kegiatan teori guru melaksanakan penilaian afektif yakni untuk menilai sikap yang dilakukan oleh peserta didik. Dan guru terkadang memerlukan bantuan dari ketua kelas untuk mencatat anggota kelasnya yang berisik ketika pembelajaran ataupun melanggar aturan yang telah ditetapkan bersama. Penilaian afektif tersebut dilaksanakan ketika pembelajaran teori ataupun praktik. Sedangkan pada kegiatan pembelajaran praktik membuat produk batik tulis, guru berusaha untuk selalu menilai hasil karya batik tulis yang dibuat oleh peserta didik. Guru muatan lokal batik tulis kelas IVA berusaha melaksanakan penilaian kognitif, afektif, dan psikomotor untuk menentukan tingkat pencapaian tujuan pembelajaran masing-masing peserta didik.

Guru muatan lokal batik tulis kelas IVA SD Muhammadiyah Bantul Kota berusaha mengadakan evaluasi walaupun jam mata pelajaran muatan lokal batik tulis hanya 2 jam pelajaran setiap minggunya. Hal tersebut dilakukan agar mengetahui apabila terdapat mata pelajaran yang tidak mudah dipahami oleh peserta didik maka guru akan berusaha untuk memperbaiki cara penyampaian materi ajar yang lebih mudah dipahami oleh peserta didik. Begitupun dalam kegiatan praktik membatik, guru berusaha mengecek satu persatu hasil karya peserta didik untuk mengetahui aspek psikomotorik dalam hal menggambar dan membuat produk batik tulis masingmasing peserta didik. Guru muatan lokal batik tulis kelas IVA berusaha melaksanakan evaluasi karena untuk memperbaiki kualitas pembelajaran serta hasil yang dicapai oleh masing-masing peserta didik. Hal tersebut dikarenakan evaluasi dilakukan untuk mengetahui berhasil atau tidaknya proses pembelajaran yang telah berlangsung (Mahirah, 2017).

\section{Strategi Guru dalam Mengembangkan Kreativitas Peserta Didik pada Pembelajaran Muatan Lokal Batik Tulis}

\section{Strategi Guru Mengembangkan Peserta Didik sebagai Individu/Pribadi (Person)}

Dalam proses belajar peserta didik terkait dengan aspek pribadi terdapat tiga komponen utama yaitu: (1) membuat batik tulis sesuai dengan keinginan dan imajinasi yang dimiliki, (2) melakukan latihan untuk menghasilkan produk yang maksimal dari berbagai sumber belajar, dan (3) memiliki jiwa yang semangat untuk melakukan suatu hal baru. Dalam hal ini tugas guru sebagai demonstrator yaitu dengan menyiapkan materi yang akan disampaikan kepada peserta didik, mempelajari materi pelajaran yang ada di buku cetak, kemudian mencari tambahan materi ajar dari sumber lainnya. Guru juga diituntut selalu kreatif dalam menjelaskan materi pelajaran,. Guru juga perlu bekerjasama menyusun perangkat pembelajaran bersama guru kelas 4 lainnya, dan menentukan tujuan pembelajaran khusus dalam setiap pertemuan agar mencapai hasil belajar yang maksimal. 
Strategi yang dilakukan guru untuk dapat mengakomodir peserta didik sebagai individu yaitu dengan empat komponen utama. Guru perlu memahami karakteristik kemampuan yang dimiliki oleh masing-masing peserta didik. Selain itu, guru juga harus berusaha menjadi pribadi yang baik agar mampu di contoh oleh peserta didiknya (Sauri, 2010). Lebih lanjut, guru harus dapat berinteraksi dan berkomunikasi dengan baik kepada peserta didik saat pembelajaran berlangsung untuk mempermudah peserta didik dalam memahami materi pelajaran (Inah, 2015). Guru juga dapat memanfaatkan sarana dan prasarana yang disediakan oleh sekolah, hal tersebut dilakukan agar peserta didik mampu mengembangkan kreativitas yang dimilikinya dengan baik.

\section{Strategi Belajar dari Lingkungan (Press)}

Dalam proses belajar peserta didik terkait dengan aspek belajar dari lingkungan, tampak empat komponen yang menjadi titik utama kegiatan seni membatik. Satu, bersemangat untuk mencari tahu motif batik yang akan digambar. Kedua, bentuk dorongan dari guru ialah mendampingi peserta didik (menggambar motif batik tulis atau mencanting). Ketiga, bentuk dorongan dari teman sekelasnya yaitu mendampingi dan memberi semangat temannya yang belum selesai menggambar ataupun mencanting. Keempat, dorongan kuat dari dalam diri peserta didik dan lingkungan sekitarnya.

Dalam hal ini peran guru dalam pengelola kelas lebih ditekankan pada proses organisasi lingkungan dan kondisi sosial kelas. Guru dalam hal ini dapat menyusun tempat duduk, menjaga kedisiplinan dan kebersihan kelas termasuk mengajarkan cara menjaga kebersihan kelas, menyediakan fasilitas kelas (internet, LCD proyektor) termasuk di dalamnya menggunakan fasilitas sekolah, menciptakan proses sosial yang akrab dalam proses sosialisasi kegiatan belajar di sekolah (Hendarwati, 2013).

Dua komponen utama dalam strategi guru dalam proses belajar dari lingkungan. Pertama yaitu untuk mengembangkan potensi kreatif yang dimilikinya dengan cara memberikan kebebasan kepada peserta didik dalam hal menggambar motif batik tulis di atas kertas ataupun di atas kain. Hal tersebut dilakukan karena guru menyadari bahwa kreativitas peserta didik berbeda-beda dan memberikan kesempatan kepada peserta didik untuk mengembangkan ide dan imajinasinya (Khanafiyah \& Rusilowati, 2010) melalui sebuah karya batik tulis. Kedua, guru dapat mendukung peserta didik dengan cara memberikan motivasi dan semangat agar mampu menghasilkan produk batik tulis yang maksimal. Dengan adanya dorongan dari guru, maka peserta didik akan merasa dirinya termotivasi untuk menghasilkan produk batik tulis yang maksimal.

\section{Strategi dalam Keahlian Berpikir Kreatif(Process)}

Dalam proses belajar peserta didik terkait dengan berpikir kreatif siswa membuat batik tulis sesuai dengan keinginannya termasuk dalam hal ini menemukan inspirasi motif yang akan digunakan. Dalam kegiatan tersebut, terjadi pula proses kerja sama dalam memanfaatkan sarana 
dan prasarana di kelas untuk mendorong rasa ingin tahu peserta didik dalam mencoba hal baru. Peran guru dalam proses berpikir kreatif ini adalh sebagai mediator yang tugas utamanya adalah untuk memilih dan menggunakan media sesuai dengan materi, berinteraksi dengan mengajukan pertanyaan kritis, berkomunikasi dengan peserta didik, mendorong tingkah laku sosial dalam pembelajaran dan mempelajari materi ajar yang disampaikan.

Strategi guru dalam kaitannya dengan meningkatkan upaya berpikir kreatif peserta didik yaitu dengan dua hal. Pertama, merangsang peserta didik untuk terlibat dalam kegiatan kreatif dengan cara menyediakan sarana dan prasarana yang mendukung serta sesuai dengan kegiatan pembelajaran yang akan dilaksanakan (Usman, 2013). Kedua, memberikan kebebasan kepada peserta didik untuk mengembangkan ide kreatif dalam hal membuat produk batik tulis, karena setiap peserta didik memiliki ide kreatif yang berbeda-beda.

\section{Strategi Guru dalam Kreativitas Berwujud (Product)}

Dalam proses ini siswa dituntut untuk menghasilkan produk batik tulis dengan maksima dengan membuat batik berdasarkan paduan komponen unsur dan prinsi dasar seni rupa (titik, garis, dan warna) (Wijaya, 2010). Dalam hal ini guru berperan sebagai fasilitator dengan menyediakan sumber belajar, memberi keleluasaan kepada peserta didik saat praktik dan menyiapkan alat dan bahan. Guru juga berperan sebagai evaluator dengan melakukan evaluasi di akhir pembelajaran termasuk melakukan penilaian dari aspek kognitif, afektif, dan psikomotor.

Strategi yang dapat dilakukan guru adalah dengan menghargai setiap karya batik tulis peserta didik dengan cara memberikan nilai akhir dan hasil membatik yang telah dibuat esok akan di perkenalkan kepada adik kelas. Walaupun terdapat kendala pembelajaran praktik membatik tidak sampai tahap mewarnai kain yang telah dicanting, akan tetapi guru berusaha untuk memberikan nilai kepada peserta didik dan menghargai setiap hasil karya peserta didik.

\section{Faktor Pendukung dan Penghambat Guru dalam Mengembangkan Kreativitas Peserta Didik pada Pembelajaran Muatan Lokal Batik Tulis}

\section{Faktor Pendukung}

Terdapat dua faktor pendukung dalam kegiatan mengembangkan kreativitas peserta didik pada pembelajaran muatan lokal batik tulis. Pertama yaitu rangsangan mental. Faktor pendorong guru pada aspek rangsangan mental bahwa guru muatan lokal batik tulis kelas IVA SD Muhammadiyah Bantul Kota memberikan kebebasan kepada peserta didik untuk menggambar motif sesuai dengan imajinasi mereka. Meskipun demikian arahan tetap diperlukan dalam proses kegiatan yang dirasa baru bagi siswa. Kedua yaitu faktor kondisi lingkungan. Dengan adanya kondisi lingkungan belajar yang nyaman, siswa dapat berdiskusi dan penggunaan berbagai metode lainnya. Dalam pembelajaran praktik, guru memanfaatkan ruang kelas dengan baik termasuk menggunakan halaman kelas. Selain itu, faktor lingkungan lainnya yaitu orang tua dan teman- 
teman sehingga peserta didik dapat semangat sehingga mampu menyelesaikan produk batik tulis yang dibuatnya. Dengan adanya dorongan semangat dari lingkungan sekitar maka akan membuat peserta didik bersemangat dan percaya diri akan kemampuan yang dimilikinya (Permadi, 2015).

\section{Faktor Penghambat}

Terdapat empat faktor penghambat dalam pengembangan kreativitas siswa dalam kegiatan membatik tulis. Pertama terkait dengan proses evaluasi yang dalam hal ini adanya penundaan pelaksanaan penliaian praktik karena kekurangan waktu. Kedua, terkait dengan hadiah yang pernah diberikan guru untuk memberikan reward. Ketiga yaitu adanya persaingan yang dalam hal ini disajikan contoh motif batik tulis dari kakak kelas sebagai contoh justru menjadi pembanding motif produk akhir batik tulis yang dibuat. Keempat adanya pembatasan lingkungan dalam belajar seni (Marsiano dkk., 2019; Permadi, 2015). Dalam pembelajaran teori guru tidak mengharuskan peserta didik untuk menguasai materi batik tulis sesuai dengan keinginannya dikarenakan mata pelajaran batik hanya mata pelajaran muatan lokal, jadi guru tidak terlalu memaksakan. Sedangkan dalam kegiatan praktik guru tidak mengharuskan peserta didik untuk membuat desain motif batik tulis di atas kertas.

\section{SIMPULAN DAN SARAN}

\section{Simpulan}

Proses kreativitas peserta didik kelas IV A SD Muhammadiyah Bantul Kota dalam membuat kerajinan batik tulis berlangsung dengan baik, yakni dari aspek pribadi (person), pendorong (press), proses (process), dan produk (product). Guru dalam mengembangkan kreativitas peserta didik kelas IV A SD Muhammadiyah Bantul Kota pada mata pelajaran muatan lokal batik tulis mampu menjalankan perannya dengan baik, yakni sebagai demonstrator, pengelola kelas, mediator, fasilitator, dan evaluator. Faktor pendukung guru dalam mengembangkan kreativitas peserta didik kelas IV A di SD Muhammadiyah Bantul Kota ialah rangsangan mental melalui pemberian kebebasan kepada peserta didik untuk membuat batik tulis sesuai dengan ide yang dimiliki serta mampu menghargai hasil karya peserta didik dan kondisi lingkungan yang mendukung yakni adanya dorongan dari guru, orangtua, dan teman kelas. Sedangkan faktor penghambat guru dalam mengembangkan kreativitas peserta didik kelas IV A di SD Muhammadiyah Bantul Kota ialah penundaan evaluasi, pemberian hadiah, persaingan, dan lingkungan yang membatasi.

\section{Saran}

Terdapat beberapa saran yang dapat dihasilkan dari penelitian ini. Pertama, bagi peserta didik, diharapkan mampu menambah ilmu pengetahuan dan wawasan mengenai batik tulis dengan cara mencari referensi dari sumber belajar yang beranekaragam, agar kelak mampu melestarikan kerajinan khas daerahnya. Kedua, bagi guru, diharapkan meningkatkan perannya sebagai 
demonstrator, pengelola kelas, mediator, fasilitator, serta evaluator agar tujuan pembelajaran yang telah di rencanakan mampu tercapai secara maksimal. Ketiga, bagi sekolah, diharapkan mampu menyediakan guru muatan lokal batik tulis yang berasal dari jurusan seni sehingga mampu menguasai pembelajaran mengenai batik tulis lebih baik lagi.

\section{DAFTAR RUJUKAN}

Ardianti, S. D., Pratiwi, I. A., \& Kanzunnudin, M. (2017). Implementasi Project Based Learning (PJBL) Berpendekatan Science Edutainment Terhadap Kreativitas Peserta Didik. Refleksi Edukatika : Jurnal Ilmiah Kependidikan. https://doi.org/10.24176/re.v7i2.1225

Arini, A. M. dan A. B. (2011). Batik: Warisan Adiluhung Nusantara. G-Media.

Astuti, R., \& Aziz, T. (2019). Integrasi Pengembangan Kreativitas Anak Usia Dini di TK Kanisius Sorowajan Yogyakarta. Jurnal Obsesi: Jurnal Pendidikan Anak Usia Dini. https://doi.org/10.31004/obsesi.v3i2.99

Basari, A. (2014). Penguatan Kurikulum Muatan Lokal dalam Pembelajaran di Sekolah Dasar. Seminar Nasional Imu Pendidikan.

Euis, Y. R. dan K. (2010). Strategi Pengembangan Kreativitas pada Anak. Kencana.

Falconer, E. G., Cropley, D. H., \& Dollard, M. F. (2018). An Exploration of Creativity in Primary School Children. International Journal of Creativity and Problem Solving.

Hanif, S., Wijaya, A. F. C., \& Winarno, N. (2019). Enhancing Students' Creativity through STEM Project-Based Learning. Journal of Science Learning. https://doi.org/10.17509/jsl.v2i2.13271

Hendarwati, E. (2013). Pengaruh pemanfaatan lingkungan sebagai sumber belajar melalui metode inkuiri terhadap hasil belajar siswa SDN I Sribit Delanggu pada pelajaran IPS. Pedagogia: Jurnal Pendidikan, 2(1), 59-70.

Inah, E. N. (2015). Peran komunikasi dalam interaksi guru dan siswa. Al-Ta'dib, 8(2), 150-167.

Ishak, M., Dyah Jekti, D. S., \& Sridana, N. (2017). Pengaruh Penerapan Pendekatan Saintifik Menggunakan Model Pembelajaran Discovery Dan Kooperatif Tipe Stad Terhadap Kemampuan Berpikir Kreatif Peserta Didik SDN 13 Ampenan. Jurnal Pijar MIPA. https://doi.org/10.29303/jpm.v12i1.326

Khanafiyah, S., \& Rusilowati, A. (2010). Penerapan pendekatan modified free inquiry sebagai upaya meningkatkan kreativitas mahasiswa calon guru dalam mengembangkan jenis eksperimen dan pemahaman terhadap materi fisika. Jurnal Penelitian Pendidikan, 27(2).

Latifah, N. N., Artharina, F. P., \& Arifin, Z. (2019). Analisis Pencapaian Kompetensi Kognitif Dalam Pembelajaran Muatan Lokal Bahasa Jawa Materi Tembang. Journal for Lesson and Learning Studies. https://doi.org/10.23887/jlls.v2i2.19156

Lian, B., Kristiawan, M., \& Fitriya, R. (2018). Giving creativity room to students through the friendly school's program. International Journal of Scientific and Technology Research.

Mahirah, B. (2017). Evaluasi belajar peserta didik (siswa). Idaarah: Jurnal Manajemen Pendidikan, 1(2).

Mardiah. (2020). Peran Guru Dalam Mengatasi Kesulitan Belajar Siswa Pada Mata Pelajaran Matematika di MI Ummul Qura. BADA'A: Jurnal Ilmiah Pendidikan Dasar, Vol. 2, No, Hal. 35-64.

Marsiano, E., Nerosti, N., \& Astuti, F. (2019). Faktor-Faktor Penghambat Pembelajaran Seni Budaya (Seni Tari) di SMP Negeri 4 Padang. Jurnal Sendratasik, 7(4), 11-19. 
Martin, L., \& Wilson, N. (2017). Defining Creativity with Discovery. Creativity Research Journal. https://doi.org/10.1080/10400419.2017.1376543

Maryen, E. J., Fatubun, A. B., \& Rosely, J. (2018). Peran Guru Dalam Meningkatan Prestasi Belajar Siswa Mata Pelajaran Bahasa Indonesia di Kelas V SD Negri 2 Ridge 1 Biak. Metodik Didaktik. https://doi.org/10.17509/md.v14i1.10703

Ma'unah, S., Ulfa, S., \& Adi, E. (2020). Pengembangan Kurikulum Muatan Lokal Sebagai Upaya Pelestarian Budaya Seni Musik Hadrah Al-Banjari. JINOTEP (Jurnal Inovasi dan Teknologi Pembelajaran): Kajian dan Riset Dalam Teknologi Pembelajaran. https://doi.org/10.17977/um031v7i12020p042

Permadi, A. (2015). Faktor Pendukung dan Penghambat Media Pembelajaran Seni Budaya di SMPN 1 Tegalsari Banyuwangi. Jurnal Seni Rupa, 3(2).

Permatasari, B. I. (2018). Kreativitas Dan Hasil Belajar. De Fermat: Jurnal Pendidikan Matematika. https://doi.org/10.36277/defermat.v1i1.15

Pontoh, W. P. (2013). Peranan komunikasi interpersonal guru dalam meningkatkan pengetahuan anak. Acta Diurna Komunikasi, 2(1).

Qur'ani, D., Kuswandi, D., \& Wedi, A. (2019). Pengembangan Perangkat Pembelajaran Sinektik Berbantuan Video Pada Materi Batik Tulis Kelas XI MAN 1 Madiun. JINOTEP (Jurnal Inovasi dan Teknologi Pembelajaran) Kajian dan Riset dalam Teknologi Pembelajaran. https://doi.org/10.17977/um031v6i12019p051

Rante, H., \& Safrodin, M. (2019). Learning batik through gaming. International Electronics Symposium on Knowledge Creation and Intelligent Computing, IES-KCIC 2018 Proceedings. https://doi.org/10.1109/KCIC.2018.8628519

Samawi, M. I. (2010). Penetapan Membatik Sebagai Muatan Lokal Wajib Bagi Sekolah / Madrasah Di Kabupaten Bantul. Keputusan Bupati Bantul Nomor 05a Tahun 2010.

Sani, R. A. (2013). Inovasi pembelajaran. Jakarta: Bumi Aksara.

Sauri, S. (2010). Membangun karakter bangsa melalui pembinaan profesionalisme guru berbasis pendidikan nilai. Jurnal Pendidikan Karakter, 2(2), 1-15.

Thuneberg, H. M., Salmi, H. S., \& Bogner, F. X. (2018). How creativity, autonomy and visual reasoning contribute to cognitive learning in a STEAM hands-on inquiry-based math module. Thinking Skills and Creativity. https://doi.org/10.1016/j.tsc.2018.07.003

Usman, M. U. (2013). Menjadi Guru Profesional. PT Remaja Rosdakarya.

Wijaya, H. (2010). Titik sebagai Dasar Penciptaan Karya Seni. Humaniora, 1(2), 253-262. 